\title{
Short Communication: Chemical composition, antioxidant and antimicrobial activity of Fagonia longispina (Zygophyllaceae) of Algerian
}

\author{
LAID ZIANE ${ }^{1,2, \boldsymbol{v}}$, MOHAMMED DJELLOULI ${ }^{2}$, ABDELAZIZ BERREGHIOUA ${ }^{2}$ \\ ${ }^{1}$ Laboratory of Chemistry and Science Environment, Tahri Mohammed Béchar University. BP 417 Bechar 08000, Algeria. Tel. +21349819024, fax. \\ +660416640, `email: ziane.laid@univ-bechar.dz \\ ${ }^{2}$ Department of Material Sciences, Faculty of Exact Sciences, Tahri Mohammed Béchar University. BP 417 Bechar 08000 Algeria.
}

Manuscript received: 2 May 2021. Revision accepted: 28 May 2021.

\begin{abstract}
Ziane L, Djellouli M, Berreghioua A. 2021. Short Communication: Chemical composition, antioxidant and antimicrobial activity of Fagonia longispina (Zygophyllaceae) of Algerian. Biodiversitas 22: 3448-3453. The study's aim is to discover the antioxidant, antibacterial efficacy and identifying the main constituents of the essential oil of Fagonia longispina from southwest of Algeria. The essential oil from the aerial parts of the endemic plant $F$. longispina collected from the region of Sahara southwest of Algeria was isolated by hydrodistillation and analyzed by gas chromatography-mass spectrometry. Our work was designed then, to evaluate the antioxidant activity of the essential oil of $F$. longispina by DPPH free radical scavenging and HPTLC techniques. Antibacterial potency of essential oil from this plant has been tested against Staphylococcus aureus (ATCC 29213), Escherichia coli (ATCC 25922), and Bacillus cereus (ATCC11778) by disk diffusion assay. We found that the chemical profile of the essential oil revealed the presence of 14 compounds: Trans-pinocarveol (3.14\%), panisaldehyd (4.24\%), trans geraniol (3.05\%), carvacrol 18.72\%), elemicin (22.85\%), (Z,E) farnesol (15.69\%), caryophyllene oxide (2.68\%), alpha-curcumene (1.75\%), germacrene D (4.22\%), longipinane $(2.89 \%)$ and $\alpha$-terpinine $(2.74 \%)$. The antioxidant assay showed that the essential oil could scavenge DPPH (IC50 values of $2.1959 \mathrm{mg} / \mathrm{mL}$ free radical. The essential oil exhibits very effective antimicrobial activity using disk diffusion assay method with minimum inhibitory concentration ranging from $0.75 \mu \mathrm{L} / \mathrm{mL}$ to $1.9714 \mu \mathrm{L} / \mathrm{mL}$. These results showed that this native plant may be a good candidate for further biological and pharmacological investigations.
\end{abstract}

Keywords: essential oil, Fagonia longispina, antimicrobial activity, GC-MS

\section{INTRODUCTION}

A large number of plants (fragrant, therapeutic, zest) have intriguing organic properties which empowered them to be applied in different zones, to be specific in medication, drug store and cosmetology (Alaa et al. 2017). Herbs can contain a wide assortment of cell reinforcements atoms, for example, phenolic compounds, nitrogen compounds, nutrients, terpenoids and so forth, which group's a critical cancer prevention agent movement (Pirbalouti et al. 2013). Nowadays there is a developing interest in normal items showing cell reinforcement properties that are provided to human and creature living beings as food parts or as explicit precaution drugs. The plant realm offers a wide scope of characteristic cancer prevention agents and antimicrobials. However, there is still a lack of understanding regarding the practical utility of the majority of them. Antioxidant phenolic acids, flavonoids, and alkaloids are common secondary plant metabolites found in a variety of fruits, vegetables, and herbs. By interfering with oxidizing agents and free radicals, they have been shown to provide protection against cancer and oxidative stress (Campanella et al. 2003; Djellouli et al. 2015; Zulueta et al. 2007; Ziane et al. 2020).

The woody plant Fagonia longispina belongs to the Zygophyllaceae family. It reaches a height of 10 to 20 centimeters. It's a small plant with ground-level branches radiating outwards from the base. The whole plant is shrouded in coarse hairs that tie sand. This plant has purplish flowers with a bright red. $F$. longispina is a common plant that goes by the nickname "Atlihia" and used as a common herbal medicine. Previous research has shown that $F$. longispina contains a number of secondary metabolites, including a wide range of antioxidants such as tannins, flavonoids, and saponins. (Hamidi et al. 2012).

The antioxidant activity of $F$. longispina is reported for the second time here (Hamidi et al. 2014), however, there are other antioxidant studies for other species in the same family as the paper reported by Satpute et al. (2012) for the Fagonia arabica and Rashid et al. (2019) for the $F$. longispina. Fagonia olivieri is a form of Fagonia (Rashid et al. 2019). The aerial plant could provide remedy for cancer in its early stages, it'is a plant traditionally used for the treatment of various skin lesions and for the treatment of various other diseases of digestive in the southwest of Algeria (Saoura region of Bechar) Northern Africa. This work aimed to perform a preliminary screening of radical scavenging activities of the extracts isolated from $F$. longispina (Zygophyllaceae) (Hamidi et al. 2012; Djellouli et al. 2013). 


\section{MATERIALS AND METHODS}

\section{Plant material}

Aerial parts of $F$. longispina were collected in March 2016 from Boukais, Southwestern Algeria (Figure 1), and reported by the National Agency of Nature Protection (ANN) in Bechar, Algeria (Hamidi et al. 2012; 2014).

\section{Extraction of essential oil}

The dried aerial parts of $F$. longispina $(1 \mathrm{~kg})$ were subjected to hydrodistillation for $5 \mathrm{~h}$ in 3 times using a Clevenger-type apparatus, according to the method outlined by the European Pharmacopoeia (Council of Europe 1997). Then, the essential oil was then separated from the aqueous layer, dried over anhydrous sodium sulfate. The calculated average of essential oil yield is $0.0392 \%$. The essential oil was stored in sealed vials at low temperature $\left(4^{\circ} \mathrm{C}\right)$ until (GC- MS) analysis.

\section{GC-MS analysis}

A Hewlett Packard Agilent 6890 GC system was used for the study coupled with a 5973C MS. HP-5 MS analytical fused silica capillary column $(30 \mathrm{~m} \times 0.25 \mathrm{~mm} \times$ $0.25 \mu \mathrm{m}$, Agilent, Santa Clara, CA) was used for chromatographic separations. For both columns, the oven temperature had ramped from $60^{\circ} \mathrm{C}$ to $250^{\circ} \mathrm{C}(8 \mathrm{~min})$ at $2^{\circ} \mathrm{C} / \mathrm{min}$ isothermal for $10 \mathrm{~min}$. The flow rate of the helium was $0.5 \mathrm{~mL} / \mathrm{min}$. The retention indices for all components were determined according to the method using n-alkanes as standard.

\section{Identification of components}

Individual constituents were detected and registered by comparing their mass spectra to those of known compounds stored in the spectral database of the National Institute of Standards and Technology (NIST), which was connected to the GC-MS instrument.

\section{Determination of antioxidant activity by DPPH method}

The determination of the antioxidant potential essential oils was on the basis of their scavenging activity of the stable 1,1-diphenyl-2-picrylhydrazyl (DPPH) free radical. To summarize, $100 \mathrm{NL}$ of different concentrations of each extract in methanol were applied to $1.9 \mathrm{~mL}$ of a DPPH methanol solution (0.004 percent). The mixture was vigorously shaken before being allowed to rest for 30 minutes at room temperature.

A solution of $100 \mathrm{NL}$ methanol and $1.9 \mathrm{~mL}$ DPPH was used as the control. The DPPH radical scavenging activity was represented as an inhibition percentage using the following equation (Benmehdi et al. 2013):

\section{\% Inhibition $=[(\mathrm{AB}-\mathrm{AS}) / \mathrm{AB}] \times 100$}

Where: $A B$ represents the absorbance of the control reaction (which includes all reagents except the test compound) and AS represents the absorbance of the test compound.

Ascorbic acid is an antioxidant that has been used as a reference or a supportive control in studies. The experiments were performed three times. The extract concentration providing 50 percent inhibition (IC50) was determined from the graph of inhibition percentage plotted against extract concentration $(0.5 ; 0.25 ; 0.125 ; 0.0625$; $0.0312 ; 0.0156 ; 0.0078 \mathrm{mg} / \mathrm{mL}$ )

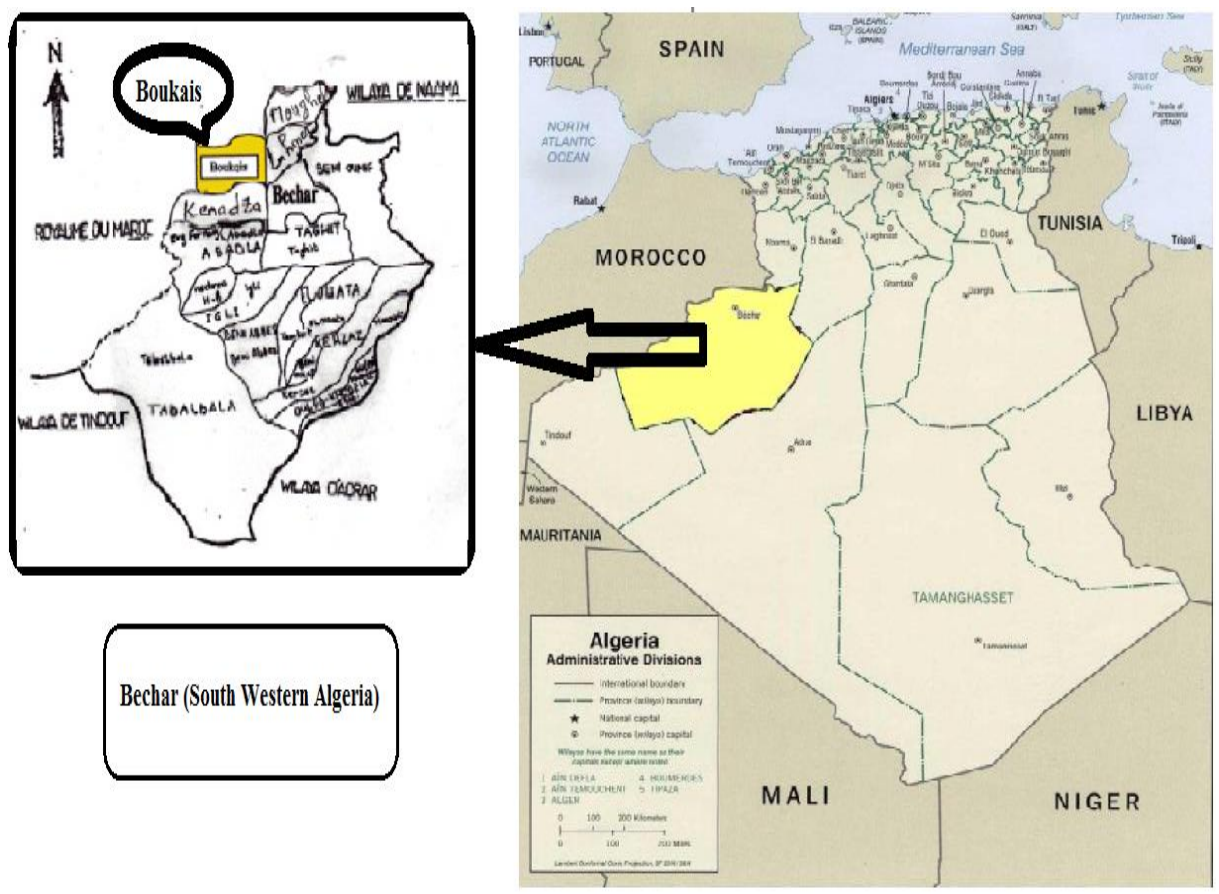

Figure 1. Location of Bechar area in yellow on the map of Algeria (Hamidi et al. 2012; Djellouli et al. 2013) 
High-performance thin-layer chromatography (TLC) study of extracts and DPPH

Essential oil of $F$. longispina was submitted to thinlayer chromatography (TLC) to High performance on silica gel plate (20x $20 \mathrm{~cm}$, Silica gel F254, Merck). Methanol and chloroform $(40: 60 \mathrm{v} / \mathrm{v})$ were used to create a solvent system that was tailored for essential oils of $F$. longispina. essential oils was based on a TLC silica gel plate, which was grown to a distance of $70 \mathrm{~mm}$ in a sandwich TLC chamber. After 15 minutes of air drying, the plate was sprayed with $0.004 \%(\mathrm{w} / \mathrm{v})$ DPPH reagent prepared in methanol and $10 \%(\mathrm{v} / \mathrm{v})$ sulphuric acid, respectively. After spraying, the plates were heated at $60^{\circ} \mathrm{C}$ for precisely 30 minutes to observe the activities (Amari et al. 2014).

\section{Antibacterial activity}

We used the disc diffusion method to screen for antibacterial activities of the essential oils against the four bacterial strains namely: Staphylococcus aureus (ATCC 29213, positive control: penicillin, Escherichia coli (ATCC 25922, positive control: gentamycin sulfate injection), and Bacillus cereus (ATCC11778). The Petri dishes were maintained by serial sub-culturing every month on nutrient agar slants and incubating at $37^{\circ} \mathrm{C}$ for $18-24 \mathrm{~h}$. The minimum inhibitory concentrations (MIC) of the extracts were determined using a serial microplate dilution assay against each test bacterial species.

\section{RESULTS AND DISCUSSION}

The chemical composition of the essential oil with their retention time, name of compounds, molecular formula, and relative percentages (Area Pct) are presented in Table 1. The essential oils (light yellow color) isolated by hydrodistillation of $F$. longispina was obtained with $0.0392 \%$, About 14 compounds were identified in the essential oil of $F$. longispina, representing approximately 98.97\% of the total mass of the essential oil (Figure 2). trans-pinocarveol $(3.14 \%)$, panisaldehyd $(4.24 \%)$, trans geraniol $(3.05 \%)$, carvacrol $18.72 \%)$, elemicin $(22.85 \%)$, (Z,E) farnesol $(15.69 \%)$, caryophyllene oxide $(2.68 \%)$, alpha-curcumene (1.75\%), germacrene D (4.22\%), longipinane $(2.89 \%)$ and $\alpha$-terpinine $(2.74 \%)$. Because of its extra electron, DPPH gives a strong absorption band at $517 \mathrm{~nm}$ in visible spectroscopy (Molyneux et al. 2004).

We remarked on the TLC plate, by using TLC bioautography technique, the appearance of zones of antiradicalaire activity of pale yellow color on purple bottom for the extracts under study as for the ascorbic acid (Hasan et al. 2009). After spraying the plates with sulphuric acid (Figure 4), purple color spots were observed and indicated the presence of several bioactive compounds in essential oils of $F$. longispina. In addition, the study revealed also the observation of yellow spots after spraying the plates with DPPH solution (Figure 3), indicating the presence of antioxidant compounds in the extracts.

\section{Antibacterial activity}

Essential oil's antibacterial function in vitro against the employed bacteria was qualitatively assessed by the presence or absence of inhibition zones (Nahar et al. 2016). The results obtained for antibacterial activity screening of $F$. longispina essential oil are summarized in Table 2. With the broth dilution method, the MIC values for essential oil of aerial parts were in the range of $0.75-1.9714 \mu \mathrm{L} / \mathrm{mL}$.

Table 1. Components detected in the essential oil of Fagonia longispina

\begin{tabular}{|c|c|c|c|c|c|}
\hline Peak & Compound & RT & RI & Formula & Conc. $(\%)$ \\
\hline 1 & $\alpha$-Terpinene & 14.57 & 1010 & $\mathrm{C}_{10} \mathrm{H}_{16}$ & 2.74 \\
\hline 2 & trans -Pinocarveol & 19.31 & 1112 & $\mathrm{C}_{10} \mathrm{H}_{16} \mathrm{O}$ & 3.14 \\
\hline 3 & Ocyl acetate & 20.39 & 1250 & $\mathrm{C}_{10} \mathrm{H}_{20} \mathrm{O}_{2}$ & 4.58 \\
\hline 4 & Panisaldehyd & 21.06 & 1257 & $\mathrm{C}_{8} \mathrm{H}_{8} \mathrm{O}_{2}$ & 4.24 \\
\hline 5 & Trans geraniol & 21.77 & 1262 & $\mathrm{C}_{10} \mathrm{H}_{18} \mathrm{O}$ & 3.05 \\
\hline 6 & Carvacrol & 22.38 & 1298 & $\mathrm{C}_{10} \mathrm{H}_{14} \mathrm{O}$ & 18.72 \\
\hline 7 & Geraniol acetate & 24.17 & 1367 & $\mathrm{C}_{12} \mathrm{H}_{20} \mathrm{O}_{2}$ & 7.12 \\
\hline 8 & Alpha-curcumene & 25.19 & 1471 & $\mathrm{C}_{15} \mathrm{H}_{22}$ & 1.75 \\
\hline 9 & Germacrene D & 25.28 & 1477 & $\mathrm{C}_{15} \mathrm{H}_{24}$ & 4.22 \\
\hline 10 & Citronellyl propionate & 26.78 & 1481 & $\mathrm{C}_{13} \mathrm{H}_{24} \mathrm{O}_{2}$ & 5.30 \\
\hline 11 & Elemicin & 27.41 & 1497 & $\mathrm{C}_{12} \mathrm{H}_{16} \mathrm{O}_{3}$ & 22.85 \\
\hline 12 & $(\mathrm{Z}, \mathrm{E})$ Farnesol & 28.24 & 1503 & $\mathrm{C}_{15} \mathrm{H}_{26} \mathrm{O}$ & 15.69 \\
\hline 13 & Longipinane & 28.79 & 1520 & $\mathrm{C}_{15} \mathrm{H}_{26}$ & 2.89 \\
\hline 14 & Caryophyllene oxide & 31.35 & 1579 & $\mathrm{C}_{15} \mathrm{H}_{24} \mathrm{O}$ & 2.68 \\
\hline \multicolumn{5}{|c|}{ a. Oxygenated monoterpenes } & 52 \\
\hline \multicolumn{5}{|c|}{ b. Monoterpenes hydrocarbons } & 2.74 \\
\hline \multicolumn{5}{|c|}{ c. Sesquiterpenes hydrocarbons } & 8.86 \\
\hline \multicolumn{5}{|c|}{ d. Oxygenated sesquiterpenes } & 18.37 \\
\hline \multicolumn{5}{|c|}{ e. Esters } & 17 \\
\hline \multicolumn{5}{|c|}{ Total oil } & 98.97 \\
\hline \multicolumn{5}{|c|}{ Number of compounds } & 14 \\
\hline
\end{tabular}

Note: RI: Retention indices relative to C8-C29 n-alkanes on the HP-5MS column; RT: Retention time 

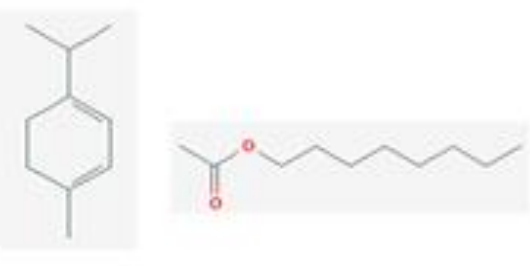

a-Terpinine

Ocyl acetate

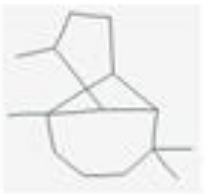

Longipinane

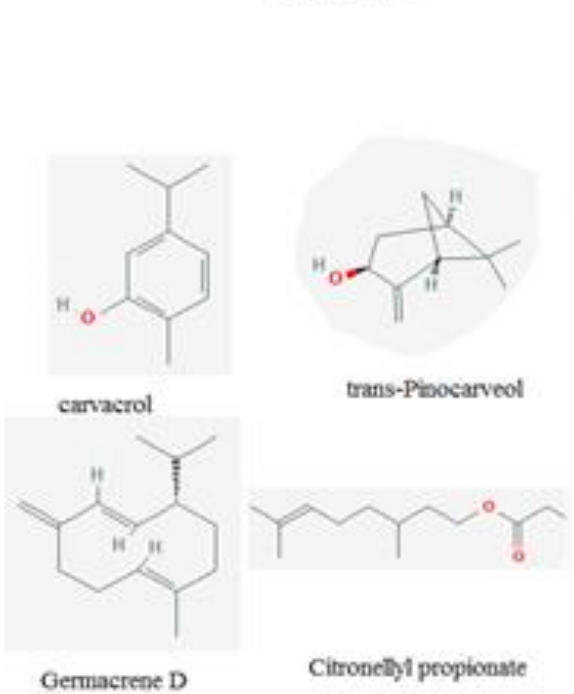

Germacrene D<smiles>COc1ccc(C=O)cc1</smiles>

p-anisaldehyde

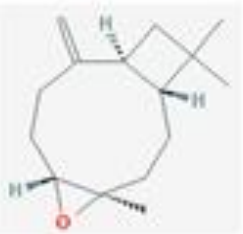

Caryophyllene oxide
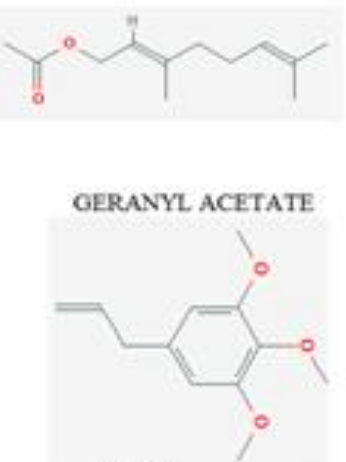

Elemicin

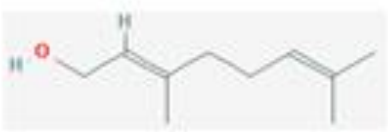

Trans geraniol

Figure 2. Components of essential oil composition

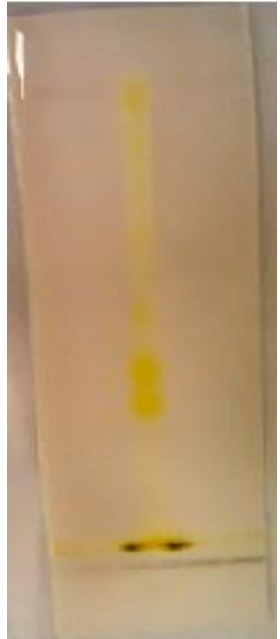

Figure 3. TLC plate after spraying with DPPH solution the yellow spots indicate the presence of antioxidant compound
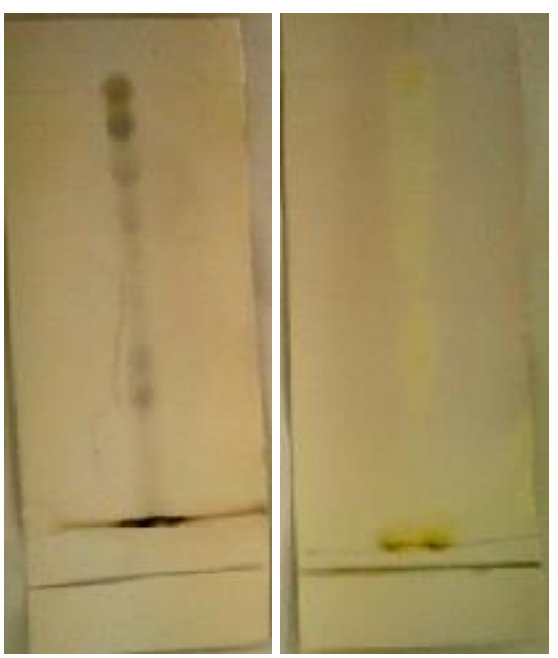

Figure 4. TLC plate after spraying with sulphuric acid the purple color spots indicate the presence of several bioactive compounds in Fagonia longispina 
Table 2. Antimicrobial activity of essential oils from Fagonia longispina

\begin{tabular}{lc}
\hline \multicolumn{1}{c}{ Organisms } & $\begin{array}{c}\text { MIC }(\boldsymbol{\mu L} / \mathbf{m L}) \\
\text { (minimum inhibitory concentration) }\end{array}$ \\
\hline Escherichia coli & 1.51 \\
Staphylococcus aureus & 1.9714 \\
Bacillus cereus & 0.75 \\
\hline
\end{tabular}

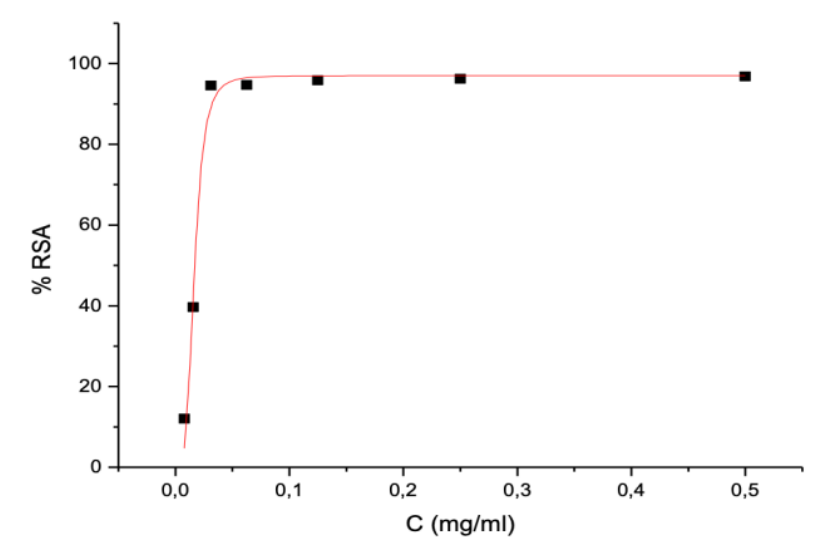

Figure 5. Radical scavenging of ascorbic acid on DPPH

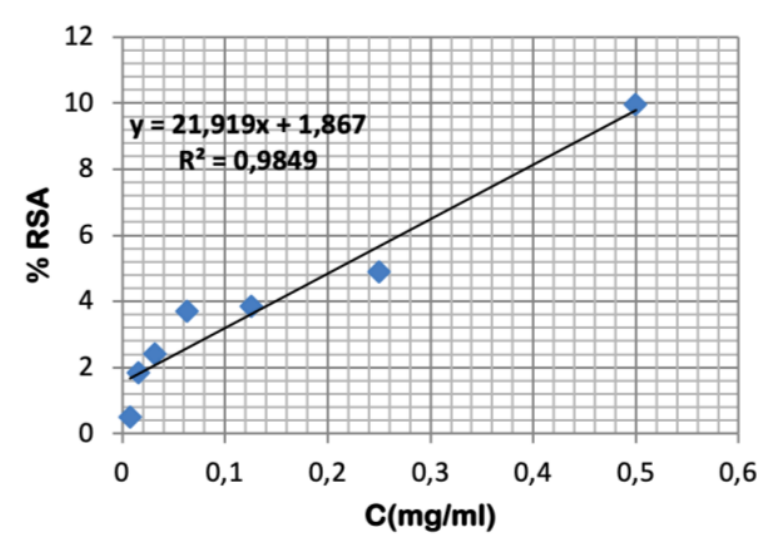

Figure 6. Radical scavenging of essential oil of Fagonia longispina on DPPH

\section{Discussion}

Aerial parts of this plant were screened for the principal classes of secondary metabolites, such as anthraquinones, terpenes, saponins, alkaloids, coumarins, flavonoids and tannins (Hamidi et al. 2012). Hamidi et al. (2014) studied phytochemical constituents in different extracts (hexane, ethyl ether and chloroform) of $F$. longispina by gas chromatography-mass spectrometry (GC-MS). This study revealed 13 compounds, and phytochemical constituents in ethyl acetate (EtOAc) extract from the aerial parts of $F$. longispina (Zygophyllaceae) by gas chromatography-mass spectrometry (GC-MS). They quantified 12 compounds (Hamidi et al. 2016). The study of Dastagir et al. 2014 described the Oxygenated monoterpenes as the major components of the plants of family Zygophyllaceae (Fagonia cretica and Tribulus terrestris) collected in Pakistan (Dastagir et al. 2014).
In the present study, we investigate the chemical profile of the essential oil of $F$. longispina using the GC-MS analysis. In $F$. longispina oils, 14 compounds were identified constituting $98.97 \%$ of the oil composition (Tables 1). Oxygenated monoterpenes (52\%), this fraction representing the major group of compounds such as; of trans-Pinocarveol (Huang et al. 2019; Bardakci et al. 2019), P-anisaldehyde (Dastagir et al. 2014), Trans geraniol (Dastagir et al. 2014), carvacrol (Sellam et al. 2012) and elemicin (Dastagir et al. 2014). Oxygenated monoterpenes have antispasmodic, sedative and tranquilizing action (Gyawali \& Kyong-Su Kim, et al. 2012). They have antimicrobial and natural antioxidant properties (Kotan et al. 2008; Kordali et al. 2009; Gundidza et al. 2009; AbuDarwish et al. 2012).

Te Oxygenated sesquiterpenes were founds with (18.37\%), comprising (Z,E) farnesol (Dastagir et al. 2014) and caryophyllene oxide (Dastagir et al. 2014; Huang et al. 2019; Sellam et al. 2012; Adaszynska-Skwirzynska et al. 2018). The esters were present with (17\%) and it consisted of ocyl acetate (Dastagir et al. 2014), geraniol acetate (Dastagir et al. 2014) and citronellyl propionate (Dastagir et al. 2014). Other minor constituents of the oil are alphacurcumene (Dastagir et al. 2014; Huang et al. 2019), germacrene D (Dastagir et al. 2014; Cherrat et al. 2014) and longipinane (Huang et al. 2019; Sellam et al. 2012) (sesquiterpenes hydrocarbons $8.86 \%$ ), $\alpha$-Terpinine (Hilal Bardakci et al. 2019; Sellam et al. 2012; Cherrat et al. 2014) (monoterpenes hydrocarbons $2.74 \%$ ).

Geographic area, climatic impact, harvest season, condition of the soil, age of the plant parts, state of used plant materials (dried or fresh), part of the plant used, time of collection, and chemotype could all contribute to these qualitative and quantitative variations in the chemical composition of essential oils. Although the DPPH test is considered simple, fast and easy to operate, the experiences showed certain difficulties in the measurement of the state of reduction: a dynamic phenomenon with fable concentration (tracks of antioxidant ppm) and accompanied with numerous trained, in certain cases unstable compounds.

Previous results have shown that antioxidant capacity of fig leaves was significantly correlated with phenolic contents (Mahmoudi et al. 2016). Antioxidant activities have recently become a topic of increasing interest to health and food science researchers as well as medical experts (Huang et al.2019). The scavenging of the stable DPPH radical is widely used method to evaluate the free radical scavenging ability of various samples, including plant extracts. This approach was used in this research for the examination of the potent antioxidant of the essential oils from Algerian species $F$. longispina.

According to the results obtained (Figures 5), and by measuring $\mathrm{IC}_{50}$ values of each extract with comparison to the ascorbic acid as an authentic simple $\mathrm{IC}_{50}=$ $0.0331 \mathrm{mg} / \mathrm{mL}$ (Benmehdi et al. 2013), the results showed that the essential oils of $F$. longispina (Figure 6) had the activity with $\mathrm{IC}_{50}$ value of $2.1959 \mathrm{mg} / \mathrm{mL}$. Generally, the antioxidant activity of essential oils is related to their major compounds. These results are in accordance with other 
antioxidant study carried on other species such the paper of Hamidi et al. (2014), Pervaiz-Iqbal et al. (2012), and Hasan et al. (2009). They are promising plants for more detailed investigation of their antioxidant properties and application possibilities. With regard to antimicrobial activity, Hamidi et al. (2014) publication has described the activity of $F$. longispina extracts against Enterococcus faecalis, Bacillus spizigenil, Salmonella heidelberg and Escherichia coli using the agar diffusion method. In the current study, the essential oils of $F$. longispina was found to have moderate to high antimicrobial activity. It showed strong inhibition against $B$. cereus and low activity against $S$. aureus. This antimicrobial activity may be due to the chemical composition of the essential oil, which is rich in oxygenated compounds.

In conclusion, this research looked into the chemical compositions, antioxidants, and antimicrobial properties of essential oils extracted from $F$. longispina. The GC-MS results revealed the presence of 14 volatile compounds. The essential oil extracted from the aerial portion of $F$. longispina had high antioxidant activity. The essential oils demonstrated a high level of antibacterial activity against both gram-positive and gram-negative bacteria.

\section{ACKNOWLEDGEMENTS}

We acknowledged the director of the Scientific and Technical Research Center in Physico-Chemical Analysis. BP 248 Algiers RP 16004 Algiers.

\section{REFERENCES}

Adaszynska-Skwirzynska M, Dzieciol M. 2018. Comparison of chemical composition and antimicrobial activity of essential oils obtained from different cultivars and morphological parts of Lavandula angustifolia. J Essential Oil Bearing Plants 21: 1532-1541. DOI: 10.1080/0972060X.2018.1526123.

Alaa S, Abdellah M, Hamadi L. 2017. Phytochemical screening, contribution to the study of the antifungal effect of flavonoids from different parts of Ziziphus lotus of South-West Algeria. Asian J Pharm Clin Res 10: 13-16. DOI: 10.22159/ajpcr.2017.v10i2.14595.

Amari NO, Bouzouina M, Berkani A, Lotmani B. 2014. Phytochemical screening and antioxidant capacity of the aerial parts of Thymelaed hirsuta L. Asian Pac J Trop Dis 4: 104-109. DOI: 10.1016/S22221808(14)60324-8.

Bardakci H, Servi H, Polatoglu K. 2019. Essential oil composition of Salvia candidissima Vahl. occidentalis Hedge, S. tomentosa Miller and $S$. heldreichiana Boiss. Ex Bentham from Turkey. J Essential Oil $\begin{array}{llll}\text { Bearing } & \text { 22: } & \text { 1467-1480. }\end{array}$ 10.1080/0972060X.2019.1682061.

Benmehdi H, Bounoua N, Amrouche A, Lahcene D, Maazouzi A. 2016. Phytochemical study, antioxidant and antimicrobial activities of Euphorbia resinifera L. Int Res $\mathrm{J}$ Pharm 4: 635-639. DOI: 10.7897/2230-8407.04910.

Campanella L, Bonanni A, Tomassetti M. 2003. Determination of the antioxidant capacity of samples of different types of tea, or of beverages based on tea or other herbal products, using a superoxide dismutase biosensor. J Pharm Biomed Anal 32: 725-736. DOI: 10.1016/s0731-7085(03)00180-8.

Cherrat L, Espina L, Bakkali M, Pag'an R, Laglaoui A. 2014. Chemical composition, antioxidant and antimicrobial properties of Mentha pulegium, Lavandula stoechas and Satureja calamintha Scheele essential oils and an evaluation of their bactericidal effect in combined processes. Innov Food Sci Emerg Technol 22: 221-229. DOI: 10.1016/j.ifset.2013.12.016.
Council of Europe. 1997. European pharmacopoeia 3th ed. Council of Europe, Strasbourg.

Dastagir G, Hussain F, Rehman IU. 2014. Essential oil composition of some plants of family Zygophyllaceae and Euphorbiaceae. Pak J Bot 46: 2043-2049.

Djellouli M, Moussaoui A, Benmehdi H, Ziane L, Belabbes A, Badraoui M, Slimani N, Hamidi N. 2013. Ethnopharmacological study and phytochemical screening of three plants (Asteraceae Family) from the region of Southwest Algeria. Asian J Nat Appl Sci 2: 59-65.

Djellouli M, Benmehdi H, Mammeri S, Moussaoui A, Ziane L, Hamidi N. 2015. Chemical constituents in the essential oil of the endemic plant Cotula cinerea (Del.) from the southwest of Algeria. Asian Pac J Trop Biomed 5 (10): 930-932. DOI: 10.1016/j.apjtb.2015.06.007.

Hamidi N, Lazouni HA, Moussaoui A, Ziane L, Saad A. 2012. GC-MS analysis of ethanol extract from the aerial parts of Fagonia longispina (family Zygophyllaceae). Asian J Nat Appl Sci 1: 136-142.

Hamidi N, Lazouni HA, Moussaoui A, Ziane L, Djellouli M, Belabbesse A. 2014. Ethnopharmacology, antibacterial and antioxidant activities, phytochemical screening of bioactive extracts from the aerial parts of Fagonia longispina. Asian J Nat Appl Sci 3 (3): 3-7.

Hamidi N, Ziane L, Djellouli M, Lazouni HA. 2016. Chemical characterization by GC-MS from the aerial parts of Fagonia longispina (Zygophyllaceae). Asian J Pharm Clin Res 9: 152-153.

Hasan SMR, Hossain Md M, Akter R, Jamila M, Mazumder Md EH, Rahman S. 2009. DPPH free radical scavenging activity of some Bangladeshi medicinal plants. J Med Plants Res 3: 875-879.

Huang X, Chen S-Y, Zhang Y, Wang Y-H, Zhang X, Bi Z-Y, Yuan H-B. 2019. Chemical composition and antifungal activity of essential oils from three Artemisia species against Alternaria solani. J Essential Oil $\begin{array}{llll}\text { Bearing } & \text { 22: } & \text { 1581-1592. }\end{array}$ 10.1080/0972060X.2019.1708812.

Mahmoudi S, Khali M, Benkhaled A, Benamirouche K, Baiti I. 2016. Phenolic and flavonoid contents, antioxidant and antimicrobial activities of leaf extracts from ten Algerian Ficus carica L. varieties. Asian Pacific J Trop Biomed 6: 239-245. DOI: 10.1016/j.apjtb.2015.12.010.

Molyneux P. 2004. The use of the stable free radical diphenylpicrylhydrazyl (DPPH) for the antioxidant activity. Songklanakarin J Sci Technol 26: 211-219.

Nahar N, Rahman Md. S, Rahman SM, Moniruzzaman M. 2016. GC-MS Analysis and antibacterial activity of Trigonella foenumgraecum against bacterial pathogens. Free Radic Antioxidants 6: 109-114. DOI: $10.5530 /$ fra.2016.1.13.

Pirbalouti AG, Setayesh M, Siahpoosh A, Mashayekhi H. 2013. Antioxidant activity, total phenolic and flavonoids contents of three herbs used as condiments and additives in pickles products. Herba Polonica 59: 51-62. DOI: 10.2478/hepo-2013-0016

Rashid U, Khan MR, Sajid M. 2019. Antioxidant, anti-inflammatory and hypoglycemic effects of Fagonia olivieri DC on STZ-nicotinamide induced diabetic rats - in vivo and in vitro study. J Ethnopharmacol 242: 112038. DOI: 10.1016/j.jep.2019.112038.

Satpute R, Bhattacharya R, Kashyap RS, Purohit HJ, Deopujari JY, Taori GM, Daginawala HF. 2012. Antioxidant potential of Fagonia arabica against the chemical ischemia-induced in PC12 cells. Iranian J Pharm Res 11: 303-313.

Sellam K, Ramchoun M, Alem C, Khallouki F, El Moualij B, El Rhaffari L. 2012. Chemical composition, antioxidant and activities of essential oil of Warionia saharae from oases of Morocco. In: Salih B, Çelikbıçak U (eds.). Gas Chromatography-Biochemicals, Narcotics and Essential Oils. IntechOpen, UK. DOI: 10.5772/32273.

Ziane L, Djellouli M, Miloudi A. 2020. Antibacterial activity and gas chromatography-mass spectrometry studies of Algerian Atriplex halimus L. Asian J Pharm Clin Res 13 (3): 84-86. DOI: 10.22159/ajpcr.2020.v13i3.36638.

Zulueta A, Esteve M, Frasquet I, Frígola A. 2007. Vitamin C, vitamin A, phenolic compounds and total antioxidant capacity of new fruit juice and skim milk mixture beverages marketed in Spain. Food Chem 103: 1365-1374. DOI: 10.1016/j.foodchem.2006.10.052. 